John Carroll University

Carroll Collected

2017 Faculty Bibliography

Faculty Bibliographies Community Homepage

$1-2017$

\title{
The Median Employee to CEO Pay Ratio Disclosure Requirement
}

Robert Bloom

John Carroll University, rbloom@jcu.edu

Follow this and additional works at: https://collected.jcu.edu/fac_bib_2017

Part of the Accounting Commons

\section{Recommended Citation}

Bloom, Robert, "The Median Employee to CEO Pay Ratio Disclosure Requirement" (2017). 2017 Faculty Bibliography. 98.

https://collected.jcu.edu/fac_bib_2017/98

This Article is brought to you for free and open access by the Faculty Bibliographies Community Homepage at Carroll Collected. It has been accepted for inclusion in 2017 Faculty Bibliography by an authorized administrator of Carroll Collected. For more information, please contact connell@jcu.edu. 


\title{
The Median Employee to CEO Pay Ratio Disclosure Requirement
}

\author{
Robert Bloom, John Carroll University
}

\begin{abstract}
In recent years, especially in national political campaigns, there has been much discussion about who is in the top $1 \%$ of American wealth, how they landed in this category, and what special income tax provisions perpetuate their status. As a reaction to this debate in this category, the Dodd Frank Act and the Consumer Protection Act of 2010 have mandated disclosure by publicly registered companies to disclose the median employee to CEO pay ratio. The Securities and Exchange Commission has issued specific guidance on this requirement. That is the subject of this article.
\end{abstract}

\section{Keywords}

compensation measure, median employee, CEO compensation, median to CEO compensation, SEC, GRI

\section{Issues of Measurement}

Securities and Exchange Commission (SEC)registered companies are expected to disclose the ratio of their median employee pay to that of their CEO or equivalent officer starting with the fiscal year beginning on or after January 1, 2017. This disclosure will appear in registration statements, proxy statements and annual reports. This article examines this requirement, how it is to be measured and its ramifications. First, the issues involved in adhering to this requirement are set forth. Then the ramifications of complying with the law are considered.

There is considerable flexibility in meeting the requirement. However, SEC Compliance and Disclosure Interpretations, Section 128CItem 402(u) Pay Ratio Disclosure, provides the commission's interpretative assistance on adhering to this law. ${ }^{1}$ There are several issues companies should be clear about in furnishing the disclosures:

1. The disclosures for the median employee do not have to be based on annual compensation for all employees, but could be provided in terms of another consistently applied compensation measure such as tax or payroll records for the employees. The alternative measure does not have to include each compensation component such as stock option awards.

2. A registrant may not use hourly or annual pay rates in the compensation 
measure to reflect the median employee since that in and of itself would not consider the number of hours worked. Additionally, attempting to convert part-time workers into full-time equivalents is not allowed; nor is annualizing the pay of employees who did not work for the entire year.

3. To compute the pay ratio, a registrant is to select a date within 3 months of the end of its fiscal year to determine the population of its employees for identifying the median. Then the registrant is required to identify the median employee from this population using annual total compensation or an alternative measure as in Point 1 above. To identify the median employee, the registrant does not have to use a period including the date on which the employee population is set; nor is a full annual period needed. The annual compensation measure could even use a period pertaining to a prior year given no change in the employee population or compensation arrangements.

4. This guidance does not address furloughed employees, so it is the responsibility of the registrant to decide whether such employees should be reflected as employees. The guidance deals with four categories of employees - full-time, part-time, temporary and seasonal. It is up to the registrant to classify its employees. A registrant may annualize the compensation for permanent employees, whether fulltime or part-time, as long as they are employed for less than a full fiscal year or on unpaid leave during the year. However, the registrant is not allowed to annualize the total compensation for temporary or seasonal employees.

5. The registrant may wish to characterize the pay ratio as an estimate in view of the flexibility in determining the median employee. As the SEC interpretation guidance suggests, there is imprecision in the process of developing the pay ratio, involving estimates, statistical analysis, assumptions and adjustments, so the final figure could very well be a reasonable estimate.

The rule allows companies to make the median employee determination once every 3 years assuming no significant change in the employee population. A company could apply a cost-of-living adjustment to the compensation measure to identify the median employee. No name of the employee is requested in this regulation. The rule also allows companies to exclude non-U.S. employees from countries whose privacy regulations do not permit companies to comply, and includes a de minimus exemption for foreign employees (i.e., if a registrant has non-U.S. employees accounting for $5 \%$ or less of its total employee population, the company may decide to exclude all of them in identifying its median employee). The registrant is additionally allowed to omit from its measurement any employees from a business combination that occurred for the fiscal year in which that event takes effect. Nevertheless, the registrant would have to indicate the acquisition and disclose the number of employees omitted. All factors considered, the registrant is required to fully disclose the methodology used to arrive at the median employee and the pay ratio.

\section{Ramifications}

A number of jurisdictions have proposed laws to tie local income tax rates or license fees to the corporate CEO pay ratio. Portland, Oregon, in particular, has approved such a proposal. "The Portland Ordinance," which has yet to be implemented, calls for a twotiered surtax on its local $2.2 \%$ city business income tax starting in 2017: companies with CEO pay ratios between 100 and 250 times the median employee's pay would be required to pay an additional $10 \%$ tax of the $2.2 \%$ tax. Companies with the pay ratio beyond 250 times the median employee's pay would be required to pay a $25 \%$ surtax. Rhode Island, Minnesota, Illinois, Massachusetts, and 
Connecticut are considering proposals similar in principle to Portland's. ${ }^{2}$

\section{Conclusion}

While the fate of Dodd-Frank is unclear in the Trump Administration, state and local jurisdictions could conceivably forge ahead with legislation mandating disclosure of the pay ratio and imposing surtaxes. This would not be surprising given the public outcry in recent years over concentration of income and wealth in the hands of the top $1 \%$ of Americans. Consequently, companies may wish to disclose this ratio even without a federal mandate as part of their commitments to sustainability performance and transparency in financial reporting. In fact, the GRI (Global Reporting Initiative) 4.0, the latest version, which many companies and not-for-profit organizations worldwide follow, calls for the following similar key performance indicator for companies adhering to its sustainability disclosures given that this metric is a material indicator of an organization's activities:

G4-66: "Report the ratio of percentage increase in annual total compensation for the organization's highest-paid individual in each country of significant operations to the median percentage increase in annual total compensation for all employees (excluding the highest-paid individual) in the same country."

Having these ratios in the public domain should make companies think hard about the justification for high CEO pay and the disparity between median employee and CEO pay packages.

It should be noted that current examples of this ratio are not available at this time in SEC proxy statements since the effective date for first reporting this disclosure is January 1, 2017. Companies will be including the ratio in their 2018 SEC proxies. However, Glassdoor Economic Research has attempted to estimate the ratio based on publicly available CEO pay for S\&P 500 companies and a sample of voluntary self-reporting by employees in those companies. ${ }^{3}$ The compensation for CEOs is from 2014 SEC filings. For reliability, Glassdoor only reflects companies with 30 or more employee reports. Glassdoor found that the average CEO compensation was $\$ 13.8$ million a year. The average median worker's compensation was $\$ 77,800$, and the average ratio of CEO pay to median worker pay is 204 , meaning that the average CEO earned 204 times what the average median worker earned. Glassdoor observed the highest ratio was for Discovery Communications with its CEO reaping \$156 million and median worker $\$ 80,000$, an astonishing pay ratio of 1,951 . The second highest set of statistics is attributable to Chipotle, with its CEO earning \$28.9 million, its median worker $\$ 19,000$, a ratio of 1,522 . The lowest set of statistics apply to Fossil, with a CEO receiving 0 compensation, emphasizing stock price increases. Glassdoor stipulates caveats applicable to the foregoing data, including that they apply to the largest companies from the S\&P 500, whose CEOs command the highest pay packages including bonuses, stock options, and restricted stock plans. Also, CEO compensation at such companies can vary dramatically from year to year. Additionally, the comparison between CEO and median worker pay is not comparing apples to apples in the sense that the CEO compensation incorporates a number of nonsalary items whereas employee self-reported compensation often omits or understates nonsalary items. Finally, the reporting by employees may not accurately reflect that actual distribution of employees throughout the companies in terms of skilled versus unskilled labor.

\section{Declaration of Conflicting Interests}

The author declared no potential conflicts of interest with respect to the research, authorship, and/or publication of this article.

\section{Funding}

The author received no financial support for the research, authorship, and/or publication of this article.

\section{Note}

1. SEC Adopts Interpretive Guidance on Pay Ratio Rule. (2017, September 21). 
Retrieved from https://www.sec.gov/news/ press-release/2017-172

2. Kalfen, D. (2017, March 30). States and Municipalities Propose CEO Pay Ratio Tax. Retrieved from https:/www.meridiancp.com/ insights/news/states-municipalities-proposeceo-pay-ratio-tax/

3. Chamberlain, A. (2015, August 25). CEO to worker pay ratios: Average CEO earns 204 times median worker pay. Retrieved from https://www.glassdoor.com/research/ceopay-ratio/ 